\title{
MEMBANGUN KOMUNIKASI INTIM PASANGAN MUSLIM NIKAH MUDA DALAM PENDEKATAN PSIKOLOGI PERKEMBANGAN DAN AGAMA
}

\author{
Yunita Sari \\ Fakultas Psikologi Universitas Islam Bandung
}

\begin{abstract}
Marriage in young people becomes popular among moslem in Indonesian. Unfortunately, the statistic of divorce is also increases every year. Divorce much happen among couples at the first five years of marriage. Communication is the major cause of the divorce. Developmental Psychology approach assumes that couple can built healthy communication with full of affection through confirmation, self disclosure and sexual communication. Furthermore, Islam suggests the moslem to take Rasulullah (prophet Muhammad Saw.) as their model in the ways of his communication among his family members. The two perspectives can be developed as intervention technique to reduce the statistic of divorce in Indonesia.
\end{abstract}

Keywords :marriage, intimate communication, developmental psychology approach

\section{Pendahuluan}

Di dalam Undang-Undang Perkawinan No. 1 Tahun 1974 dinyatakan bahwa tujuan perkawinan adalah mencapai kebahagiaan. Secara lebih khusus di dalam agama Islam, perkawinan atau pernikahan adalah sebuah lembaga dimana seorang laki-laki dan perempuan saling berpasangan dan secara sah bersatu untuk membentuk sebuah keluarga sakinah mawaddah warahmah. Setelah menikah, pasangan suami isteri diharapkan dapat saling berbagi dan memahami berbagai perbedaan masing - masing pasangan. Perbedaan-perbedaan tersebut dapat berupa perbedaan-perbedaan dari aspek fisik, psikologis, sosial ekonomi, pendidikan maupun aspek sosial budaya yang dibawa oleh suami maupun isteri sebelum mereka menikah.

Hal ini sesuai dengan QS. Al Hujurat: 13 yaitu :

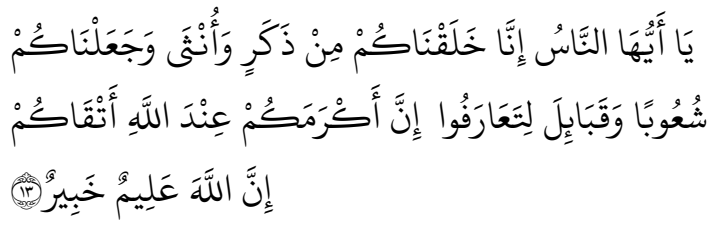

"Hai manusia, sesungguhnya Kami menciptakan kamu dari seorang laki-laki dan seorang perempuan dan menjadikan kamu berbangsa-bangsa dan bersuku-suku supaya kamu saling mengenal. Sesungguhnya orang yang paling mulia di antara kamu adalah orang yang paling bertakwa di antara kamu. Sesungguhnya Allah Maha Mengetahui lagi Maha Mengenal".

Dengan adanya berbagai perbedaan ini sebenarnya pasangan suami isteri diharapkan untuk dapat saling mengisi dan mengkompromikan perbedaan - perbedaan tersebut melalui proses komunikasi agar terjalin suatu keharmonisan dan penyesuaian di dalam rumah tangga mereka terutama di awalawal pernikahan. 
Pada saat sekarang, menikah di usia muda semakin menjadi trend. Berdasarkan penelitian Lois Hoffman dan kawan-kawan (Adhim, 2002) tentang menikah pada usia dewasa muda (young adulthood) yakni dari usia 18 tahun sampai sekitar 24 tahun, angka statistik di Amerika menunjukkan 34,6\% perempuan usia 20-24 dan 21,4\% laki-laki usia yang sama melakukan pernikahan, sementara mereka masih menempuh studi di perguruan tinggi. Salah satu hal yang mempengaruhi keputusan mereka untuk menikah bukan kumpul kebo, sebagai mana lazimnya terjadi di Amerika, akan tetapi adanya komitmen. Selain komitmen, faktor lain sangat berpengaruh terhadap keputusan untuk menikah pada usia muda adalah tanggung jawab. Para laki-laki dan juga perempuan di Amerika memiliki sense of responsibility "rasa tanggung jawab" yang tinggi, cenderung lebih cepat mengambil keputusan menikah.

Apabila kita lihat kondisi di Indonesia, meningkatnya status gizi dan kesehatan remaja disertai pengaruh hormon seksual yang mulai diproduksi pada saat remaja menyebabkan kematangan organ seksual menjadi lebih cepat. Selain itu, fitnah syahwat telah merata. Banyaknya gambar-gambar yang "berbau" seksual datang silih berganti setiap hari. Media cetak serta elektronik berebut menampilkan gambar yang memancing birahi, sehingga pemuda-pemuda semakin penasaran. Dengan menikah di usia muda dapat menjadi salah satu alternatif para remaja agar tidak terseret dalam pergaulan seks bebas (Rahmawati,2001).
Menurut pakar psikologi, Diane E. Papalia dan Slly Wendkos Olds (dalam Adhim, 2002) mengemukakan bahwa usia terbaik untuk menikah bagi perempuan adalah 19-25 tahun, sedangkan bagi laki-laki usia 20-25 tahun seharusnya sudah menikah. Ini adalah usia terbaik untuk menikah, baik untuk memulai kehidupan rumah tangga maupun untuk menjadi pengasuh anak pertama (the first time parenting). Selain itu, hasil penelitian Campbell dan kawan-kawan menunjukkan bahwa yang paling bahagia di antara pasangan nikah adalah pasangan yang menikah pada usia 20-an (Papalia \& Olds dalam Adhim, 2002).

Berdasarkan hukum perkawinan di Indonesia yaitu Undang-Undang No. 1 pasal 7 tahun 1974 mengatur bahwa perkawinan atau pernikahan hanya diijinkan jika calon mempelai pria telah berusia 19 tahun dan mempelai wanita telah berusia 16 tahun. Dengan alasan pada usia tersebut individu dianggap telah dapat membuat keputusan sendiri dan telah dewasa dalam berpikir dan bertindak. Jika salah satu dari calon mempelai belum memenuhi persyaratan usia tersebut, dapat meminta dispensasi kepada pengadilan atau pejabat lain yang ditunjuk oleh orang tua pihak pria maupun wanita, meskipun demikian untuk menikah masih tetap diperlukan ijin orangtua. Bilamana individu telah mencapai usia di atas 21 tahun, barulah individu boleh menikah tanpa ijin orangtua. Melihat kebijakan pemerintah tentang batasan usia perkawinan ini, maka dapat dipahami bahwa sebetulnya usia di bawah 21 tahun merupakan usia yang rentan untuk memulai suatu perkawinan. Namun 
kenyataannya, akhir-akhir ini, menikah tidak hanya dilakukan oleh individu yang sudah dikatakan dewasa, tetapi banyak remaja akhir khususnya mahasiswa yang telah melangsungkan pernikahan pada usia muda, baik itu sesuai dengan usia persyaratan ataupun di bawah usia persyaratan. Mereka dapat dikatakan merupakan pasangan nikah muda.

Menurut Hertog Saud, Kepala Badan Koordinasi Keluarga Berencana Nasional (BKKBN) Jawa Barat, dari 1.000 penduduk, ada 126 jiwa penduduk di Jawa Barat usia 1519 tahun yang sudah menikah. Sementara di Yogyakarta hanya 34 orang dan Jawa Tengah dan Jawa Timur masing-masing berkisar 70 orang (Kompas.com, 2006). Kebanyakan motif perkawinan di usia muda adalah hanya untuk mengejar kebutuhan sesaat, misalnya seks dan kesenangan. Bila hal ini terjadi maka sangat besar kemungkinan keluarga yang dibina tidak akan harmonis dan tujuan perkawinan itu sendiri tidak dapat tercapai (Walgito dalam Wisnubroto, 2008).

Apabila kita mengacu pada Al-Qur'an, dijelaskan bahwa menikah merupakan salah satu cara untuk menghindarkan diri untuk berbuat zina (Q.S Al Isro:32 ) dan Islam sangat menganjurkan pernikahan setelah mencukupi usia perkembangannya. Hal ini mengacu pada sebuah hadits :

"Wahai para pemuda barang siapa di antara kamu mempunyai kemampuan untuk menikah, maka nikahlah sebab nikah dapat menundukkan pandangan dan memelihara kemaluan..”(H.R Bukhari).
Berdasarkan hadits tersebut, Islam menyerukan pernikahan setelah pemuda mempunyai kemampuan untuk menikah. Pemuda atau syabab yang dimaksud adalah seorang yang telah mencapai masa aqil baligh (13-17 tahunan) dan belum mencapai tiga puluh tahun (Adhim, 2002) Namun demikian, salah satu syarat aqil baligh adalah adanya sifat rasyid atau kecendekiaan. Secara sederhana, orang yang telah memiliki sifat rasyid mampu mengambil pertimbanganpertimbangan yang sehat dan berdasar dalam memutuskan suatu perkara, dapat menimbang baik dan buruk dengan ilmu yang memadai, mampu memilih yang penting dan kurang penting dan bersikap mandiri. Hal ini juga dapat mengacu pada Q.S Annisa : 6. Dengan kata lain, menikah dianjurkan pada individu yang mampu bersikap dewasa atau matang secara psikologis.

Norman Sprinthall dan W. Andrew Collin, dalam bukunya "Adolescent Psychology (1995) mengatakan bahwa gejolak syahwat yang semula meledak-ledak akan berubah menjadi stabil ketika menikah usia dini. Boleh jadi seorang suami memiliki hasrat seks yang sangat tinggi itu stabil dan mendapatkan muaranya untuk menemukan persentuhan agung secara teratur dan halal (legitimized), jiwanya akan tenang, emosinya akan berubah menjadi lebih positif, sehingga dapat mengembangkan potensi-potensi yang ada pada dirinya secara lebih optimal. Ini berarti bahwa pernikahan dini tidak menghambat pengembangan potensi diri, termasuk prestasi akademik. Justru sebaliknya, 
pernikahan dini seharusnya memacu kita untuk lebih maju. Hal ini tentu saja sangat sesuai dengan Islam yang menganjurkan pernikahan bagi individu yang telah memiliki kemampuan.

Meskipun terdapat banyak kebaikan dalam sebuah pernikahan, pasangan suami isteri yang menikah muda ini harus mempersiapkan diri berkaitan dengan sifat rasyid atau matang secara psikologis. Hal ini dikarenakan usia yang muda sangat rentan dengan permasalahan atau pun konflik. Usia dewasa muda atau masa dewasa awal merupakan masa transisi dari tahapan perkembangan remaja menuju tahapan dewasa. Berdasarkan Aliah B. Purwakania Hasan (2008), pada masa usia dewasa muda, mereka tidak hanya belajar untuk mandiri dari segi penghasilan, belajar menjadi lebih matang dari segi emosi dan meninggalkan masa remaja. Namun, kemungkinan muncul krisis seperempat usia pada masa ini. Karakteristik krisis pada masa ini salah satunya adalah evaluasi terhadap hubungan intim dan kesepian. Setelah kegembiraan memasuki usia dewasa dan segala tanggung jawabnya, banyak individu yang mengalami kondisi emosi abuabu.

Menurut Hurlock (1994), pada tahapan dewasa awal diharapkannya individu untuk dapat memainkan peran-peran baru sesuai dengan pola-pola kehidupan yang baru dan harapan-harapan sosial yang baru daripada waktu dia anak-anak atau remaja. Masa dewasa awal merupakan masa penetapan "settle down", masa reproduktif, masa ketegangan emosional, masa bermasalah, masa keterasingan sosial, masa komitmen, masa saling ketergantungan, masa perubahan nilai, masa penyesuaian diri dengan gaya hidup baru dan masa kreatif. Selain itu, usia dewasa awal atau dewasa muda merupakan batas akhir masa remaja yang penuh dengan gejolak dan perubahan, baik secara fisik maupun psikis, sehingga dikhawatirkan belum dapat menerima segala bentuk tanggung jawab yang dituntut dari adanya sebuah perkawinan . Padahal untuk menciptakan kehidupan rumah tangga yang harmonis, persiapan diri dalam hal psikologis sangat dibutuhkan . Maka dari itu, pernikahan pasangan muslim di usia muda perlu dibekali berbagai pengetahuan mengenai pernikahan dan konsekuensinya.

\section{Perceraian dan Permasalahan Komunikasi}

Berdasarkan ungkapan Dirjen Bimas Islam Departemen Agama, Nazaruddin Umar, dalam acara Pembukaan Pemilihan Keluarga Sakinah dan Pemilihan Kepala KUA Teladan Tingkat Nasional, di Asrama haji, Pondok Gede, Jakarta (14/8) Indonesia berada di peringkat tertinggi memiliki angka perceraian paling banyak dalam setiap tahunnya, dibandingkan negara Islam di dunia lainnya. Hal ini semakin bertambah pada tiga tahun terakhir. Setiap tahun ada 2 juta perkawinan di Indonesia, tetapi tingkat perceraian bertambah menjadi dua kali lipat sehingga setiap 100 orang yang menikah, 10 pasangannya bercerai, dan umumnya adalah pasangan yang baru menikah. Selain itu, Dirjen Bimas Islam Departemen Agama, Nazaruddin Umar, mengungkapkan bahwa "Dalam Al-Quran 80 
persen ayat membicarakan tentang penguatan bangunan rumah tangga, hanya sebagian kecil yang membicarakan masalah penguatan negara, bangsa apalagi masyarakat, sebab keluarga adalah sendi dasar terciptanya masyarakat yang ideal, mana mungkin negara dibangun di atas bangunan keluarga yang berantakan,“.(Asydhad, Arifin 2008)

Selain itu, berdasarkan studi yang dilakukan beberapa ahli di Amerika bahwa $50 \%$ pernikahan pertama berakhir dengan perceraian dan 20\%-nya terjadi pada dua tahun pertama dari pernikahan tersebut (Weiten dalam Ladd,1996). Fakta lain menunjukkan hasil penelitian yang dilakukan terhadap 120 pasangan suami istri yang bercerai di Pengadilan Agama Bandung, 45\% berada di bawah usia pernikahan kurang dari lima tahun (Kompas, Juli 2003). Data lain mengenai perceraian yang diperoleh untuk kota Bandung sebagai salah satu kota besar di Indonesia adalah 30.900 kasus perceraian, 13.415 di antaranya cerai talak dan 15.139 cerai gugat. (Perceraian, 2007). Penelitian lain di Amerika menunjukkan bahwa permasalahan komunikasi (poor communication), yaitu sebesar $68 \%$ adalah permasalahan tertinggi pada kasus-kasus pernikahan, dibandingkan dengan permasalahan-permasalahan lain di dalam pernikahan (Weiten dalam Ladd, 1996).

Berdasarkan fakta di atas, perceraian menjadi fenomena yang terjadi di masyarakat Indonesia saat ini terutama bagi pasangan muda. Meskipun data pasangan muda yang bercerai tidak secara spesifik diketahui usia mereka berapa dan juga bagaimana pernikahan tersebut dibangun, apakah karena terpaksa (married by accident) atau dikarenakan komitmen yang kuat terhadap pernikahan, namun cukup menjadi kekhawatiran bagi perkembangan keluarga Islam di Indonesia. Pada dasarnya, Al-Qur'an telah menjelaskan bahwa perceraian itu adalah suatu perbuatan yang halal tetapi paling dibenci Allah. Namun demikian tetap angka perceraian semakin tinggi dari tahun ke tahun. Aspek komunikasi pun menjadi salah satu faktor perceraian yang banyak terjadi.

\section{Pentingnya Komunikasi di antara Pasangan} Nikah

Menurut Duvall (1977) salah satu bentuk tugas perkembangan yang harus dilalui pasangan suami isteri pada tahapan awal pernikahan mereka adalah pasangan mampu membangun suatu bentuk komunikasi timbal balik yang memuaskan dan berusaha untuk saling mengkompromikan kebutuhan masingmasing pasangan suami isteri. Mengapa menjalin komunikasi di antara pasangan suami isteri menjadi hal yang penting bagi kelangsungan dan keharmonisan keluarga atau pernikahan? Hal ini dikarenakan:

1. Komunikasi merefleksikan kesulitan dan kekuatan yang terjadi di dalam pernikahan dan akan berkaitan dengan aspek kehidupan lainnya serta memprediksikan kepuasan pernikahan di masa yang akan datang maupun perpecahan di antara pasangan (Ledere dan Jackson, 1969; Levenger dan Senn,1967; Navran, 1967; dan Raush, 
Barry, Hertel dan Swain,1974 dikutip dari Edwin J.Thomas, 1977)

2. Komunikasi merupakan suatu sarana dan cara bagi pasangan suami isteri untuk dapat menjembatani berbagai perbedaan di antara pasangan. Pada saat perbedaan-perbedaan dalam diri masing-masing pasangan sulit untuk disatukan maka perlu adanya suatu cara agar pendapat dan perasaan kedua belah pihak terakomodasi sehingga terciptanya penyesuaian di antara pasangan (Laswell, 1987).

3. Komunikasi mengharuskan pasangan suami isteri untuk belajar mengenali dan memahami bagaimana perilaku pasangannya dalam berkomunikasi dan juga bagaimana menyampaikan kebutuhan masing-masing pasangan. Hal ini dikarenakan komunikasi tidak hanya berperan sebagai pengirim pesan atau transformator namun ia juga berperan untuk mengubah dan membentuk suatu struktur serta penyesuaian di dalam hubungan interpersonal pasangan suami isteri maupun pada sistem yang ada di dalam keluarga (Galvin \& Brommel, 1982).

4. Komunikasi pada pasangan suami isteri menjadi hal yang penting dikarenakan proses penyesuaian di antara pasangan terus-menerus terjadi dan berproses seiring dengan tahapan perkembangan suami maupun isteri. Selain itu, komunikasi adalah suatu proses sentral dalam berelasi di dalam keluarga dan cara untuk melakukan suatu proses penyesuaian. Hal ini dikarenakan proses penyesuaian yang efektif tergantung dari proses berbagi pesan (sharing) di antara anggota keluarga atau pasangan suami isteri (Galvin dan Brommell,1982).

\section{Islam Membahas Mengenai Komunikasi.}

Al-Qur'an secara spesifik tidak membicarakan masalah komunikasi, Namun, jika diteliti ada banyak ayat yang memberikan gambaran umum prinsip-prinsip komunikasi. Dalam hal ini, penulis akan merujuk kepada term-term khusus yang diasumsikan sebagai penjelasan dari prinsip-prinsip komunikasi tersebut. Antara lain, term qaulan balighan, qaulan maisuran, qaulan kariman, qaulan ma'rufan, qaulan layyinan, qaulan sadidan, juga termasuk qaul al-zur (Hakim IMZI, A. Husnul : 2008)

\section{a. Prinsip Qaul Baligh}

Secara rinci para pakar sastra membuat kriteria-kriteria khusus tentang suatu pesan dianggap balīgh, antara lain:

- Tertampungnya seluruh pesan dalam kalimat yang disampaikan

- Kalimatnya tidak bertele-tele, juga tidak terlalu pendek sehingga pengertiannya menjadi kabur

- Pilihan kosa katanya tidak dirasakan asing bagi si pendengar

- Kesesuaian kandungan dan gaya bahasa dengan lawan bicara

- Kesesuaian dengan tata bahasa 


\section{b. Prinsip Qaul Karim}

Term karim dirangkai dengan kata qaul atau perkataan, maka berarti suatu perkataan yang menjadikan pihak lain tetap dalam kemuliaan, atau perkataan yang membawa manfaat bagi pihak lain tanpa bermaksud merendahkan. Sehingga qaul karim adalah setiap perkataan yang dikenal lembut, baik, yang mengandung unsur pemuliaan dan penghormatan.

\section{c. Prinsip Qaul Maisur}

Pada prinsipnya, qaul maisur adalah segala bentuk perkataan yang baik, lembut, dan melegakan. Ada juga yang menjelaskan, qaul maisur adalah menjawab dengan cara yang sangat baik, perkataan yang lembut dan tidak mengada-ada. Ada juga yang mengidentikkan qaul maisur dengan qaul ma'ruf. Artinya, perkataan yang maisur adalah ucapan yang wajar dan sudah dikenal sebagai perkataan yang baik bagi masyarakat setempat.

d. Prinsip Qaul Ma'ruf

Menurut Ibn 'Asyur, qaul ma'ruf adalah perkataan baik yang melegakan dan menyenangkan lawan bicaranya.

\section{e. Prinsip Qaul Layyin}

Sementara yang dimaksud dengan qaul layyin adalah perkataan yang mengandung anjuran, ajakan, pemberian contoh, di mana si pembicara berusaha meyakinkan pihak lain bahwa apa yang disampaikan adalah benar dan rasional, dengan tidak bermaksud merendahkan pendapat atau pandangan orang yang diajak bicara tersebut. Dengan demikian, qaul layyin adalah salah satu metode dakwah, karena tujuan utama dakwah adalah mengajak orang lain kepada kebenaran, bukan untuk memaksa dan unjuk kekuatan.

\section{f. Prinsip Qaul Sadid}

Sementara berkaitan dengan qaul sadid, terdapat banyak penafsiran, antara lain, perkataan yang jujur dan tepat sasaran, perkataan yang lembut dan mengandung pemuliaan bagi pihak lain, pembicaraan yang tepat sasaran dan logis, perkataan yang tidak menyakitkan pihak lain, perkataan yang memiliki kesesuaian antara yang diucapkan dengan apa yang ada di dalam hatinya.

\section{g. Prinsip Qaul Zur}

Asal makna kata zur adalah menyimpang/melenceng (ma ill). Perkataan zur dimaknai kizb (dusta), karena menyimpang/melenceng dari yang semestinya atau yang dituju.

Prinsip-prinsip komunikasi di atas merupakan landasan berkomunikasi dalam Islam namun perlu diperhatikan mengenai teknik atau cara menyampaikan suatu informasi atau berkomunikasi dengan orang lain. Hal ini ditegaskan oleh al-Qur`an:

"Maka disebabkan rahmat Allah kamu berlaku lemah lembut terhadap mereka. Sekiranya kamu bersikap keras lagi berhati kasar, tentulah mereka menjauhkan diri dari sekelilingmu..." (QS. Ali 'Imran: 159)

Ayat ini secara khusus ditujukan Rasulullah Saw., namun, secara umum, adalah dimaksud untuk mendidik umatnya, bagaimana cara menyikapi orang yang menolak kebenaran yang disampaikan kepadanya sebagai upaya untuk membangun sebuah komunikasi yang 
baik itu, yaitu dengan bersikap lembut dan santun, serta bertutur kata yang baik. Maka dari itu, Islam senantiasa mengajarkan kita untuk bertutur kata dengan cara yang baik dan penuh penghargaan pada orang lain terutama pada keluarga atau pasangan kita. Rasulullah sebagai tauladan melakukan berbagai perilaku komunikasi pada keluarganya yaitu :

- Pada saat berkomunikasi diniatkan karena cinta dan kasih sayang yang tulus karena Allah.

- Memanggil nama anggota keluarganya atau isterinya dengan panggilan yang menyenangkan seperti ketika Rasulullah memanggil Aisyah dengan sebutan 'Ya Humairo' atau Ya Aalsy (orang-orang yang hidup).

- Berkomunikasi dengan tenang sehingga dapat menyampaikan pesan sesuai dengan misinya, penuh makna dan mengandung nilai kebaikan dan penuh kelembutan. Sekalipun ketika beliau menegur Aisyah di saat Aisyah membuang makanan yang dikirim oleh Ummu Salamah.

- Rasulullah mengiringi bahasa lisannya dengan bahasa tubuhnya. Dari Aisyah: "bahwa Rasulullah, biasa mencium istrinya setelah wudhu, kemudian beliau sholat dan tidak mengulangi wudhunya."

- Beliau menyampaikan pesan dengan kalimat yang sederhana (tidak berteletele). Pada saat Aisyah marah, Rasulullah bersabda kepadanya: "Hai
Aisyah, berlaku lembutlah, sesungguhnya apabila Allah menghendaki kebaikan kepada sebuah keluarga maka Allah akan memberikan kelembutan kepada mereka.

- Berlapang dada. Berlapang dada dengan kelemahan yang ada dalam anggota keluarga, sehingga komunikasi dimulai dengan memaafkan kesalahan mereka terlebih dahulu. Anas berkata: "saya tidak pernah mendengar Rasulullah Saw. berkata, mengapa kamu tidak melaksanakan ini, mengapa kamu tidak melaksanakan itu, mengapa kamu tidak begini dan mengapa kamu tidak begitu. Padahal dia tinggal bersama Rasulullah selama sepuluh tahun.

Semua pesan dalam komunikasi Rasululah selalu menyenangkan untuk didengar, mudah untuk dipahami dan bersemangat untuk direspon. Komunikasi yang penuh dengan kelembutan dan kasih sayang senantiasa ditunjukkan oleh Rasulullah. Begitu pula komunikasi intim yang akan penulis sampaikan, sangat erat kaitannya dengan komunikasi yang ditunjukkan oleh Rasulullah.

\section{Teori Komunikasi Intim}

Meskipun komunikasi dilakukan sehari-hari oleh pasangan suami isteri namun seringkali kemampuan untuk melakukan komunikasi yang sifatnya mampu mengakomodasi kebutuhan masing-masing pasangan masih sulit untuk dilakukan. Maka 
dari itu, komunikasi pada pasangan suami isteri memiliki kekhasan tersendiri dan lebih menekankan pada relasi yang sifatnya intim dan penuh dengan penghargaan. Komunikasi yang penuh penghargaan atau disebut juga komunikasi intim adalah kemampuan pasangan suami isteri melakukan penyampaian dan penerimaan pesan (proses komunikasi) yang penuh penghargaan serta ditunjukkan secara verbal (kata-kata) maupun non verbal (bahasa tubuh) di antara pasangan suami isteri yang didalamnya melibatkan penerimaan pada pasangan sebagai bentuk komitmen terhadap pernikahan (Galvin dan Brommel :1982).

Menurut Galvin dan Brommel (1982) komunikasi dengan penuh penerimaan dan penghargaan atau yang disebut dengan komunikasi intim, memiliki peran dalam meningkatkan kedekatan secara emosional pada pasangan suami isteri. Kebutuhan pasangan suami isteri dalam berelasi tentu tidak terlepas dari kebutuhan emosional. Pernikahan juga merupakan suatu hubungan interpersonal yang sangat spesial dan intim bagi dua orang individu (Brehm, Sharon S. et.al, 2002). Suami atau isteri akan mengetahui bahwa dirinya dicintai, disayangi dan dihargai melalui tingkah laku verbal maupun non verbal pasangannya, seperti bagaimana ia berbicara, apa yang ia katakan, bagaimana ia memandang dan bagaimana ia menyentuh pasangannya. Semua hal di atas merupakan suatu bentuk komunikasi yang melibatkan emosi pasangan suami isteri. Selain itu, untuk dapat melakukan komunikasi intim di antara pasangan suami isteri ini, sangat dibutuhkan pemahaman terhadap diri dan pasangan.

Menurut Galvin dan Brommell (1982), komunikasi memberi kontribusi dalam menciptakan keintiman di antara anggota keluarga termasuk pasangan nikah muda. Komunikasi yang penuh kasih sayang pada dasarnya meliputi keintiman atau hubungan interpersonal yang spesial dalam proses sharing atau berbagi di antara pasangan suami isteri.

Terdapat beberapa bentuk perilaku komunikasi yang mampu mengembangkan keintiman di dalam pernikahan (Galvin dan Brommell :1982). Perilaku tersebut adalah :

1. Konfirmasi atau mengecek persamaan persepsi pasangan terhadap suatu pesan (confirmation)

2. Adanya keterbukaan dalam berkomunikasi mengenai permasalahanpermasalahan yang terjadi di dalam relasi dengan pasangan (Self Disclosure).

3. Mengkomunikasikan kebutuhan serta permasalahan seksual dengan terbuka pada pasangan (Sexual Communication).

Di dalam melakukan suatu komunikasi intim di antara pasangan suami isteri, akan terjadi suatu proses konfirmasi (confirmation), keterbukaan (self disclosure), dan juga komunikasi seksual (sexual communication) yang saling memiliki keterkaitan antara satu dimensi dengan dimensi lainnya.

Pertama, pada proses konfirmasi, pasangan dapat saling mengklarifikasi pesan 
dan memperoleh pesan yang sama terhadap kebutuhan masing-masing pasangan serta mampu merespon pesan yang disampaikan pasangan dengan penuh penghargaan. Sedangkan perilaku confirming adalah perilaku dimana individu mengkomunikasikan adanya penerimaan pada pasangan dan memberikan perhatian pada keberadaan pasangannya. Pasangan nikah muda seringkali menunjukkan gejolak emosi dalam berkomunikasi dengan pasangannya. Pada saat permasalahan belum jelas seringkali tidak dilakukan konfirmasi. Di bawah ini adalah perilaku yang dapat dilakukan pasangan nikah muda dalam melakukan konfirmasi :

1. Mendengarkan secara aktif apa yang disampaikan pasangan. Ini berkaitan dengan mendengarkan secara seksama apa yang disampaikan, berlatih untuk lebih menahan diri (bersabar) untuk tidak memotong pembicaraan, berkonsentrasi atau fokus terhadap apa yang dibicarakan dan menanggapi respon pasangan dengan tepat. Hal ini akan memunculkan adanya penghargaan kita pada pasangan yaitu bahwa kita benar-benar mendengarkan apa yang disampaikan pasangan sehingga pasangan akan merasa didengarkan dan dipahami perasaannya.

2. Mengklarifikasi apa yang disampaikan oleh pasangannya dengan bertanya mengenai perilaku pasangan yang belum dipahami oleh pasangannya sehingga terjadi komunikasi dua arah atau dialog dan bukan monolog (menginterpretasikan secara personal) dan mengecek persamaan persepsi pasangan dengan cara yang penuh dengan lemah lembut dan kalimat yang sederhana. Hal ini dilakukan agar dalam proses interaksi pasangan suami isteri mengetahui dan paham terhadap perasaan dan pemikiran pasangan.

3. Pasangan suami isteri belajar untuk menunjukkan perilaku-perilaku yang penuh perhatian, penuh kehangatan dan juga kasih sayang yang sifatnya intim pada pasangan. Iringi bahasa lisan dengan bahasa tubuh, ekspresi, intonasi dan volume suara yang sesuai. Contohnya, memeluk isteri pada saat isteri melakukan sharing sambil menangis atau menggenggam tangan suami pada saat suami butuh dukungan. Hal ini dikarenakan, perilaku verbal maupun non verbal seperti sentuhan, kontak mata, pelukan atau gesture merupakan simbol dari diterimanya pesan dengan baik.

4. Mengungkapkan permasalahan dengan tenang, jujur, tidak tergesa-gesa dan fokus pada permasalahan yang sedang dibicarakan, sebisa mungkin menghindari mengungkit - ungkit permasalahan yang lalu.

5. Mengungkapkan segala sesuatu dengan asertif. Asertif adalah suatu kemampuan untuk mengkomunikasikan apa yang diinginkan, dirasakan dan dipikirkan kepada orang lain 
namun dengan tetap menjaga dan menghargai hak-hak serta perasaan pasangan.

6. Pada saat pasangan mengungkapkan kata-kata yang mengecewakan, atau pada saat mendesak kita akan berargumentasi, membela diri atau meluruskan suatu fakta berlatihlah menahan diri dan ungkapkan hal tersebut pada saat yang benar-benar tepat seperti memperhatikan kondisi pasangan apakah siap menerima feedback.

Confirmation memainkan peran dalam perkembangan relasi intim. Tidak dapat di duga jika beberapa tingkah laku di pandang sebagai reward dan di respon dengan perilaku equivalent atau sama, akan menghasilkan hubungan timbal balik yang menguntungkan. Bagi suami atau isteri untuk menjadi intim dengan pasangannya, setiap orang harus merasa diterima dan dihargai atau diperhatikan oleh yang lain.

Kedua, self disclosure terjadi ketika pasangan nikah secara sukarela menceritakan rahasia dirinya pada pasangannya yang mungkin tidak ditemui pasangan dari orang lain. (Pearce and Sharp, 1973). Hal ini melibatkan adanya kesediaan dalam memberikan informasi dan menerima resiko dalam menceritakannya karena hal tersebut sifatnya rahasia. Dalam membangun suatu relasi atau hubungan yang lebih tinggi tingkatannya, pasangan akan melalui suatu proses yang melibatkan adanya keterbukaan yang sifatnya timbal balik yang tentu akan mengemukakan mengenai permasalahan masa lalu, sekarang dan yang akan datang. Kita dapat membuat prediksi tentang bagaimana pasangan dapat menjalin suatu keterbukaan yang sifatnya lebih positif.

Keterbukaan yang tinggi dan bersifat timbal balik lebih sering diasosiasikan dengan hubungan voluntary yang dapat mencapai perasaan kasih sayang secara timbal balik atau tingkatan kestabilan yang merupakan salah satu karakteristik dari confirmation dan afection. Keterbukaan yang sifatnya negatif dapat menyebabkan hubungan nonvoluntary dan juga salah satu karakteristik dari terciptanya konflik dan kemarahan. Keterbukaan memiliki hal yang penting di dalam pernikahan, hal ini seringkali terjadi beberapa permasalahan seperti perbedaan, kesalahpahaman atau kemarahan yang tidak terungkapkan dalam suatu relasi pasangan suami isteri. Beberapa penelitian menunjukkan bahwa: Perempuan memiliki karakteristik lebih mudah terbuka dibandingkan dengan laki-laki (Jourard dan Lasakow,1958; Komarovsky, 1967; Gilbert dan Whiteneck,1976). Selain itu, penelitian dari Levinger dan Senn (1967) juga mengemukakan bahwa keterbukaan pasangan saling berhubungan dengan kepuasan dalam pernikahan. Semakin dekat seseorang maka hubungan tersebut semakin cepat berubah maka terdapat hal-hal positif maupun negatif yang tampak dari relasi tersebut sehingga kepuasan dalam perkawinan menjadi meningkat ataupun menurun. Semakin tinggi keterbukaan semakin tinggi rasa puas namun 
hal ini tergantung dari bentuk keterbukaan itu sendiri apakah mengenai hal negatif atau positif yang diinformasikan. Selain itu cara dalam menyampaikan informasi tersebut juga menjadi hal yang penting. Pasangan yang menikah muda dituntut untuk mengungkapkan harapan dan keinginannya secara terbuka pada pasangan dengan cara yang baik.

Self esteem pun dapat mempengaruhi keterbukaan di dalam relasi pasangan suami isteri. Satir (1972) mengungkapkan bahwa self esteem merupakan dasar dari terbentuknya komunikasi yang sifatnya positif di dalam keluarga. Hal yang paling sering terlupakan di dalam komunikasi pasangan suami isteri adalah membuka perasaan yang sifatnya positif pada pasangan. Pada saat pasangan terstimulasi untuk bersikap mesra atau lemah lembut, hendaknya pasangan memperlihatkannya sebelum perasaan atau moment tersebut hilang. Melalui suatu keterbukaan yang positif, seperti menyampaikan hal-hal baik yang dirasakan oleh suami maupun isteri, pasangan suami isteri dapat lebih jujur dan terbuka dalam mengungkapkan perasaan-perasaannya terhadap pasangannya yang sifatnya sangat rahasia sekali pun.

Agar keterbukaan dapat menciptakan suatu hubungan yang sifatnya intim maka pasangan suami isteri hendaknya :

1. Meluangkan waktu bersama untuk saling berbagi atau sharing.

2. Pasangan saling mendukung untuk terciptanya keterbukaan yang sifatnya dua arah untuk dapat saling berbagi dan terbuka satu sama lain.
3. Menjaga kepercayaan pasangan untuk menjaga rahasia bersama.

4. Melakukan penerimaan terhadap proses perubahan yang terjadi akibat keterbukaan masing-masing pasangan.

Ketiga, sexual communication mengacu pada bagaimana mengkomunikasikan kebutuhan serta permasalahan seksual dengan terbuka pada pasangan. Pasangan nikah muda hendaknya memiliki pengetahuan dan pemahaman yang memadai tentang permasalahan seksual. Perbedaan antara lakilaki dan perempuan dalam permasalahan seksual dapat menjadi pemicu permasalahan seksual pada pasangan nikah. Hal ini dikarenakan sebagian besar orang memandang seks merupakan suatu relasi di dalam pernikahan yang hanya berkaitan dengan penampilan fisik. Seks sebenarnya melibatkan identitas seksual pasangan, latar belakang isu seksual yang dialami, persepsi akan masingmasing kebutuhan pasangan dan pesan dalam menyampaikan ekspresi seksual pada pasangan. Semua hal di atas berkaitan secara langsung dengan komunikasi yang sifatnya conforming dan non conforming.

Feldman

(1979) menekankan pentingnya relasi seksual di dalam keintiman pernikahan, hal ini dikarenakan dampak dari kualitas relasi seksual berkaitan dengan bentuk afeksi atau relasi kasih sayang dan pengetahuan yang mendalam mengenai masing-masing pasangan.

Scoresby mendukung pernyataan bahwa tingkah laku seksual sebagai 
suatu bentuk komunikasi, ia mengemukakan bahwa tingkah laku seksual merupakan sumber dari pemaknaan suatu hubungan dengan kepribadian seseorang. Ia juga mengemukakan bahwa ekspresi seksual membutuhkan kejelasan pesan dari komunikasi yang efektif terhadap perasaan pasangan. Kenikmatan dalam berhubungan seksual merupakan suatu hal yang bebas untuk diberikan dengan penuh kejujuran dan cara yang penuh keintiman kepada pasangan. Hal ini juga dapat menggambarkan adanya rasa cinta dan kemesraan yang memperkuat dan meningkatkan pernikahan pasangan.

Isteri maupun suami seringkali menggunakan berbagai simbol untuk menyatakan keinginannya akan berhubungan seksual (Gagnon,1977). Lederer dan Jackson (1968) menyatakan bahwa kepuasan yang sifatnya timbal balik pada setiap pasangan yang terikat hubungan seksual tergantung dari komunikasi yang terbuka atau keterbukaan di antara pasangan karena berhubungan seksual merupakan suatu hal yang sifatnya spesial. Sehingga, meskipun seks sebagai bentuk dari komunikasi dalam mengungkapkan pesan cinta dan kasih sayang namun banyak pasangan menggunakan hubungan seksual sebagai pesan bahwa mereka marah, ingin mendominasi, kecewa atau menolak pasangan. Selain itu, bagi pasangan yang saling terikat dalam hubungan yang intim, dengan sering mengkomunikasikan kebutuhan seksual mereka maka hal tersebut akan memperdalam keintiman di antara mereka. Maka dari itu, pasangan nikah muda hendaknya mengkomunikasikan permasalahan seksual dengan bijaksana dan pada saat yang tepat serta sampaikan kebutuhan serta harapanharapan dengan penuh penghargaan pada pasangan.

Uraian di atas menggambarkan caracara membangun komunikasi intim atau komunikasi yang penuh penghargaan dan kasih sayang berdasarkan teori psikologi perkembangan dan agama. Selain itu, ada beberapa hal yang juga harus dilakukan untuk menunjang tercapainya komunikasi yang intim antara pasangan nikah muda :

a. Pasangan suami isteri hendaknya senantiasa membangun komunikasi dengan Allah Swt.

b. Mengenali, memahami dan menghargai diri sendiri

c. Mengenali, memahami dan peka terhadap pasangan termasuk memahami latar belakang keluarga pasangan, kebiasaan, alasan pasangan melakukan suatu perilaku.

d. Menambah wawasan dan keilmuan mengenai kebutuhan dan perbedaan laki-laki dan perempuan. Hal ini membantu pasangan untuk lebih mengenal pasangannya dan bagaimana mereson pasangan.

e. Menentukan waktu yang tepat bagi diri dan pasangan dalam melakukan proses berbagi pesan (sharing).

\section{Simpulan}

Pernikahan di usia muda bukan suatu halangan untuk tetap mampu menciptakan 
kebahagiaan di antara pasangan suami isteri. Seorang muslim yang baik tentu akan tampak dari akhlak atau perilakunya kepada pasangannya. Dengan aqidah dan jalinan komunikasi yang kuat dengan Allah maka dapat memudahkan pasangan nikah muda dalam menjalani bahtera rumah tangga. Pengetahuan tentang bagaimana melakukan komunikasi intim pada pasangan juga merupakan salah satu jihad untuk mewujudkan keluarga bahagia dan penuh dengan kasih sayang. Di dalam melakukan suatu komunikasi intim di antara pasangan suami isteri ini, akan terjadi suatu proses konfirmasi, keterbukaan, dan juga komunikasi seksual yang saling memiliki keterkaitan antara satu dimensi dengan dimensi lainnya. Pasangan nikah muda yang masih berada pada batasan tahapan remaja akhir atau dewasa awal seringkali menunjukkan gejolak emosi dalam berkomunikasi dengan pasangannya. Pada saat berkomunikasi hendaknya dilakukan konfirmasi terlebih dahulu. Selanjutnya, proses sharing yang terjadi akan melibatkan adanya kesediaan pada pasangan untuk memberikan informasi dan menerima konsekuensi dari hasil pembicaraan di antara pasangan yang sifatnya rahasia. Proses sharing yang terus berkelanjutan ini pun mampu membuat pasangan lebih jujur dan terbuka dalam mengungkapkan perasaan-perasaannya, termasuk dalam hal kebutuhan dan ekspresi seksual di antara mereka. Hal ini sejalan dengan tuntunan Islam untuk senantiasa berbicara dengan bahasa dan cara yang baik yang telah dicontohkan oleh Rasulullah Saw.
Dalam penjelasannya, Galvin dan Brommell (1982) menyimpulkan bahwa intisari dari komunikasi intim terletak pada penghargaan dan kepekaan pasangan suami isteri untuk dapat memahami dirinya dan juga pasangannya.

\section{Daftar Pustaka}

Adhim. M. Fauzil. (2002). Indahnya pernikahan Dini. Jakarta : Gema Insani Press

Asydhad, Arifin - (15/07/2008) detikNews Suami-Istri Beda Parpol, Angka Perceraian Meningkat. Diunduh tanggal 22 November 2008 dari http://www.detiknews.com/read/2008/0...a ian-meningkat

Brehm, Sharon S. et.al. (2002). Intimate Relationship, Third edition. New York :Mac Graw Hill Book Company

Duvall, Evelyn Millis. (1977). Marriage and Family Development. New York : .J.B. Lippincott Company Philadelpia.

Fillah, Salim. A. (2005). Bahagianya Merayakan Cinta. Yogyakarta: Pro-U Media

Galvin, K \& Brommel, Bernard J. (1982). Family Communication: Cohesion and Change. Illinois : Scott, Foresman and Company

Gray, John. ph.d. (1995). Men are from Mars, Women are from Venus_Terjemahan T. Hermaya. Jakarta : PT. Gramedia Pustaka Utama

Hasan, Aliah B. Purwakania. (2008). Psikologi Perkembangan Islami. Jakarta : Raja Grafindo Persada.

Hakim IMZI, A. Husnul. (10 Mei 2008). Prinsip-Prinsip Komunikasi Dalam AlQur`An: Suatu Kajian Tafsir Tematik. Di unduh tanggal 22 November 2008 dari http://www.ptiq.ac.id/index.php?option=c om_content\&task=view\&id=37\&Itemid= 34

Hurlock, Elizabeth B. (1999). Psikologi Perkembangan : Suatu Pendekatan Sepanjang Rentang Kehidupan Edisi Lima. Jakarta : PT. Gramedia

Kasim, Nur Atik. (03 Mei 2005). Konsep Komunikasi dalam Islam. Di unduh 
tanggal 23 November 2008 dari www.pks-jaksel.or.id.

Lasswell, Marcia \& Lasswell, Thomas. (1987). Marriage And The Family, second edition. California : Wadsworth Publishing Company

Ladd, Clayton E. Tucker. (1996). "Chapter 10 Dating, Love Marriage, and Sex". Handling Marital Problem. Buku Psychological Self-Help. Mental Health Net-on line. Melalui : http///www. selfhelp.com $(03 / 16 / 06)$

Ladd, Clayton E. Tucker. (1996). "Chapter 13 Methods for Developing Skills". Buku Psychological Self-Help. Mental Health Net-on line. Melalui : http///www. selfhelp.com $(03 / 16 / 06)$

Lois Hoffman. (2001). Nikah Dini Di unduh tanggal 22 November 2008 dari www.jokam.com (23 Maret 2008)

Modul Pelatihan Keluarga Sakinah "Smartlove". Cara cerdas Menggapai Keluarga Sakinah. Lembaga Cahaya Islam, Bandung. Tidak diterbitkan.

Masykur, M.Nazhif \& Ni'matuzzakiyah, Evi. (2005). Cinta Kita Beda!!. Yogyakarta: Pro-U Media

Rahmawati. (8 November 2001). Diunduh tanggal 22 November 2008 dari www.gemari.or.id/artikel/83/shtml,8/11/2 001

Redaksi Antara. Perceraian. Di unduh tanggal 22 November 2008 dari http://www.antara.co.id/arc/2007/7/8.

Sadarjoen, Sawitri Supardi. (2005). Konflik Marital : pemahaman konseptual, aktual dan alternatif solusinya. Bandung: PT. Refika Aditama.

Santrock, John W. (1995). Life Span Development : Perkembangan Masa Hidup Edisi 5 Jilid I dan II_ Terjemahan Achmad Chusairi S.Psi \& Juda Damanik, Drs. Jakarta : Penerbit Airlangga

Scanzoni, LD \& Scanzoni, John. (1988). Men, Women, and Change : A Sociology of Marriage and Family, third edition. New York : Mac Graw Hill Book Company.

Thomas, E.J. (1977). Marital Communication and Decision Making : Analysis, Assessment and Change. New York: The Free Press

Wisnubroto, Agung Prabowo. (27 Juni2008). Cara Pengatasan Masalah (Coping) Pada Pasangan Nikah Muda Usia. Diunduh tanggal 23 November 2008 dari http://agungprabowowisnubroto.blogspot. com/2008/06/cara-pengatasan-masalahcoping-pada.html 
Psympathic, Vol. I, No.1, 2008: 17 - 32 